Персида Лазаревић Ди Ђакомо ${ }^{1}$

https://doi.org/10.46630/phm.13.2021.02

Università degli Studi “G. d'Annunzio" Chieti-Pescara

Dipartimento di Lingue, Letterature e Culture Moderne

Pescara

\title{
ФРАНКО БЕЛО И ЊЕГОВИ СРПСКИ ЈУНАЦИ
}

\begin{abstract}
У овом раду обрађују се српске теме везане за Први светски рат присутне у делу италијанског аутора Франка Бела (Franco Bello), конкретно у ро-

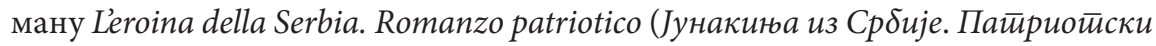
роман, 1913) и у драми L'eroe della Serbia. Dramma in 3 atti (Јунак из Србије. Драма у йри чина, 1915). Ради се о делима популарне литературе, која су се појавила на тржишту у тренутку кад се у Италији формирала средња категорија читалаца која је читала тзв. лаку књижевност. У овом случају занимљива је и чињеница да ова два дела формирају женску и мушку верзију исте теме: борбе за слободу српске јунакиње / српског јунака против Турака.
\end{abstract}

Кључне речи: италијанска књижевност, Франко Бело, српске теме, Први светски рат

\section{1. Увод}

За време Првог светског рата и између два рата у Италији формирале су се две врсте читалачке публике: „виша” и „нижа”, с обзиром на италијанске и стране романе високог квалитета, с једне стране, и на тзв. ескапистичке романе који су се продавали у великом броју: ти су романи били углавном дела страних аутора и публици су представљана на привлачан начин (RAGONE 1997: 456). Од тог тренутка, па за време фашизма, оформила се једна средња категорија читалаца у Италији која је допринела томе да се развије издаваштво тзв. лаке литературе, тј. оне врсте литературе која је била у зачетку џепне књижевности, тј. „prototascabili”, како их назива Рагоне (1997: 455). У периоду пре и после Првог светског рата, кад се уводи концепт масовног друштва, што доводи до ближег односа између издавача, интелектуалаца и читалаца (TURI 1999: 71), јачају и настају многе (мале) издавачке куће које су имале једну изравнију издавачку политику (TORTOTELI 2002: 194), као Coниоюо (Sonzogno) из Милана (данас је седиште у Венецији), Витиалано (Vitagliano) такође из

1 persida.lazarevic@unich.it 
Милана (уп. Caccia, 2013), Кватирини (Quattrini) из Фиренце (BIGIANTI 2007), као што су из Фиренце и Салани (Salani) и Нербини (SPADOLINI

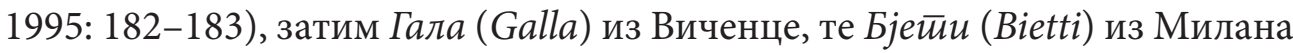
(BONETTI 1960: 29).

\section{2. Стваралаштво Франка Бела}

Са ове последње три издавачке куће, али и са другим издавачима, сарађивао је Франко Бело (Franco Bello), аутор који је у периоду око Првог светског рата, као и између два рата, посветио, између осталог, пажњу и Србији и њеној историји и традицији. Реч је о аутору о коме италијанске енциклопедије, лексикони и уџбеници књижевности не доносе никакве податке, иако је Бело објавио више од 100 књига (!), као што нам потврђује узајамни каталог италијанског националног библиотечког система (https://opac.sbn.it/opacsbn/opac/iccu/free.jsp). Истина је да су нека од тих дела, са извесним променама, чак жанровским, објављена више пута и за различите издавачке куће, али то се не суочава с чињеницом да је Бело био изузетно плодан писац. Национални библиотекарски систем Италије, међутим, пружа увид у публикације Франка Бела, које пак изискују извесну класификацију: могуће је тако видети да је за италијанску читалачку публику Бело објавио доста прерада дела познатих, али и мање познатих, страних и италијанских аутора: Шекспира, Лава Толстоја, Карла Форцанија, Проспера Меримеа, Франческа Доменика Гверација, Виктора Игоа, Жила Верна, Александра Диме, Фридриха Шилера, Алексеја Толстоја ${ }^{2}$.

2 Quando cadran le foglie...: dramma in un atto; il discorso del signor Ficchi, ovvero le ultime elezioni di Cadosso; birbonata in un atto, di Carlo Forzani ultima commedia. Monologo (Milano: Ditta S. Majocchi, 1909), Colpe dimenticate. L'uomo propone...: proverbio in due atti, per sole donne / Oreste Beltrame. Il rimorso di una vittoria: dramma in un atto (Milano: S. Majocchi, 1914), Quando cadran le foglie: Scene drammatiche in un atto (Milano: F. Bello, 1915), Anna Karenine o la storia di un cuore: Romanzo passionale dal celebre romanzo di Leone Tolstoi (Firenze: G. Nerbini, 1928), Falstaff e le allegre comari di Windsor: Romanzo eroicomico da Shakespeare (Firenze: G. Nerbini, 1928), La signora delle camelie: Romanzo passionale, dal celebre romanzo omonimo (Firenze: G. Nerbini, 1928), Il romanzo di un giovane povero: Dal celebre romanzo di Feuillet (Firenze: Casa Edit. G. Nerbini, 1928), Le due orfanelle, o una pagina dell'archivio segreto: Romanzo popolare dal celebre dramma di Adolfo d'Ennery (Firenze: G. Nerbini, 1928), I cosacchi: romanzo russo: dal romanzo omonimo di Leone Tolstoi (Firenze: Nerbini, 1929), Carmen: la cortigiana di Siviglia: grande romanzo passionale dal capolavoro di Prospero Merimee (Firenze: Nerbini, 1929), Il povero fornaretto di Venezia: Romanzo storico del sec. XVI (Firenze: G. Nerbini, 1929), Beatrice Cenci, la Vergine romana: Versione popolare dal romanzo di F. D. Guerrazzi (Firenze: G. Nerbini, 1929), I miserabili: Bozzetto drammatico in un atto. Dal capolavoro romantico di Victor Hugo (Milano: Casa Edit. Milanese, 1929), Il corriere dello zar o Michele Strogoff: Romanzo di avventure dal romanzo omonimo di Giulio Verne (Firenze: G. Nerbini, 1929), Giulietta e Romeo: Gli sventurati amanti di Verona. Romanzo storico passionale da Shakespeare (Firenze: G. Nerbini, 1929), I masnadieri: Romanzo storico. Dal dramma celebre 
У другу групу дела које је објавио спадају такође прераде дела страних и домаћих аутора, али она носе у свом поднаслову ближе одређење као „riduzione”, тј. то су скраћене верзије чувених дела, као нека врста ондашњег Reader's Digest-a ${ }^{3}$. Занимљиво је и то да је Франко Бело објавио и неколико (смањених) верзија за филм, тзв. „riduzioni cinematografiche”. Велику групу пак његових дела чине бројни историјски романи, љубавни романи, моралне приче едукативног карактера намењене младима, затим фантастични романи, модерни романи, љубавне легенде, прераде оријенталних легенди, патриотски романи и драме, мистичне драме 5 .

di Federico Schiller (Firenze: Nerbini, 1930), Ivan il terribile o lo zar sanguinario: dal romanzo storico di Alessio Tolstoi (Firenze: G. Nerbini, 1929), La Monaca di Monza: Romanzo storico. Dall'Historia patria del Ripamonti e dal processo della signora di Monza (Firenze: G. Nerbini, 1930), I misteri di Parigi: Capolavoro romantico [di] Eugenio Sue (Firenze: G. Nerbini, 1930), Otello, il moro di Venezia: romanzo storico passionale (Firenze: G. Nerbini, 1933; 1944; 1949).

3 Resurrezione: Riduzione del capolavoro di Leone Tolstoi. Romanzo passionale morale (Firenze: G. Nerbini, 1928), Quo vadis?: Riduzione dal celebre romanzo popolare di Enrico Sienkiewicz (Firenze: G. Nerbini, 1928), Lassassinio del corriere di Lione o una fatale rassomiglianza: Riduzione [dal] romanzo giudiziario di Moreau e Delacour (Firenze: G. Nerbini, 1928), La capanna dello zio Tom: dal popolarissimo romanzo di Enrichetta Beecker Stowe: Riduzione (Firenze: G. Nerbini, 1928), Manon Lescaut, l'eroina dell'amore: Romanzo passionale dal celebre romanzo dell'abate Prevost. Riduzione (Firenze: G. Nerbini, 1928), Tosca: Riduzione dal celebre dramma di V. Sardou (Firenze: G. Nerbini, 1928), Teresa Raquin: Riduzione dal romanzo di Emilio Zola (Firenze: G. Nerbini, 1929), Carlo il temerario o la Vergine della Nebbia: Romanzo storico. Riduzione [da] Walter Scott (Firenze: G. Nerbini, 1929), Pietro il grande, dominatore della Russia: Riduzione dal romanzo di Dimitri Merejkowski (Firenze: G. Nerbini, 1929), Luomo che ride: Riduzione dal celebre romanzo di Victor Hugo (Firenze: G. Nerbini, 1929), Giuseppe Balsamo, il Conte Cagliostro: Riduzione dal romanzo storico [di] Alessandro Dumas (Firenze: G. Nerbini 1930), I tre moschettieri: Riduzione [dal] romanzo di cappa e Spada [di] Alessandro Dumas (Firenze: G. Nerbini, 1930), Il fabbro del convento: Versione e riduzione [dal] romanzo storico [di] Ponson Du Terrail (Firenze: G. Nerbini, 1930), Piccolo Lord: Romanzo passionale. Riduzione dal romanzo omonimo (Firenze: G. Nerbini, 1930), I promessi sposi [di] Alessandro Manzoni: Riduzione per il popolo (Firenze: G. Nerbini, 1930), Il padrone delle ferriere: Riduzione [dal] romanzo passionale [di] Giorgio Ohnet (Firenze: G. Nerbini, 1930), Piccolo Lord: commedia in 3 atti: riduzione per soli uomini dal romanzo omonimo inglese (Vicenza: Casa Ed. G. Galla, [1946]).

4 I miserabili: Riduzione cinematografica [del] capolavoro romantico sociale di Victor Hugo (Firenze: G. Nerbini, [1927]), Casanova: Memorie d'avventure giovanili. Riduzione cinematografica (Firenze: Casa Edit. Nerbini, 1927; 1931), Memorie d’avventure giovanili: Riduzione cinematografica (Firenze: Nerbini, 1937).

5 Sangue siciliano (Milano: C. Aliprandi, [posle 1894]), Il romanzo di un tramviere: Novella sentimentale con illustrazioni dellartista Luca Fornari (Milano: Carlo Aliprandi Edit., 1903), La mamma del cardinale: Novella morale (Milano: Carlo Aliprandi Edit., 1903), Musolino: dramma in 5 atti e 5 quadri (Milano: C. Barbini, 1904), Anna Stephenson, la donna poliziotto: Avventure straordinarie (Milano: E. M. Floritta, 1909), Il club dei mal maritati: Novella Gaia (Milano: Casa Ed. E. M. Floritta, 1909), Musolino, brigante della Calabria: Dramma in 5 atti e 5 quadri. Quartetto originale. Monologo di A. Beltrami (Milano: Ditta S. Majocchi, 1909), La vendicatrice, ovvero I misteri della teppa: Romanzo moderno (Firenze: Casa Ed. G. Nerbini, 1911), 
Међу бројним Беловим издањима налазе се и три публикације које се односе на Србију: Léroina della Serbia. Romanzo patriotico (Јунакиға Cр-

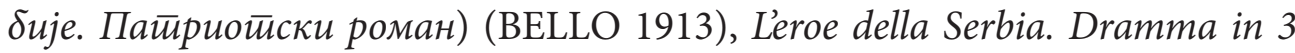
atti (Јунак Србије. Драма у тири чина) (BELLO 1915) и La Tragedia Regale

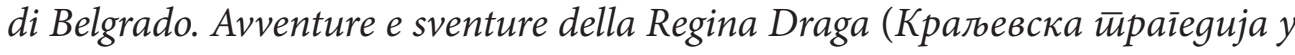
Беоіраgу. Доживљаји и неgаће краљище Драїе) (BELLO 1929). Док се издање из 1929. односи на Драгу Машин и на трагедију током Мајског преврата 29. маја 1903. године, прва два дела су у вези са балканским ратовима и са Првим светским ратом.

\section{3. Анализа романа L’eroina della Serbia. Romanzo patriotico}

Роман L'eroina della Serbia. Romanzo patriotico (Јунакиға Cрбије.

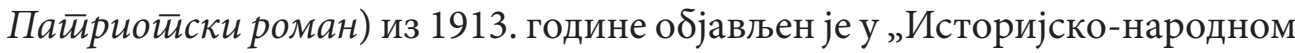
колу" издавачке куће Бјети као тринаеста књига, и требало је да то коло представља „праву библиотеку италијанског народа”, како је указивало само издање. У кратком предговору издавач је истакао славну епопеју Срба и тиме је желео да направи омаж једном народу који се бори за своју слободу:

L'Epopea gloriosa dei Serbi è magistralmente descritta in questo roman$z o$, ricco di avventure e di episodi strazianti, ove s'intreccia una pietosa storia d'amore e di eroismo sublime.

Kismet, il mendicante fatale: Leggenda araba (Milano: Casa Ed. Bietti, 1912), Leroe di Tripoli: romanzo (Milano: Casa Ed. Bietti, 1913), L’Aquilotto o il re di Roma: romanzo storico (Firenze: Nerbini, 1913), Allombra della croce: bozzetto drammatico in un atto (Milano: F. Bello, 1913), Il trovatello del reggimento: Grande romanzo militare (Torino: Casa Ed. E. M. Floritta, 1914), Oberdan: dramma patriottico in 5 atti (Milano: S. Majocchi, 1915), Il giro del mondo di un biricchino in aeroplano: Avventure straordinarie di cielo, di terra e di Mare (Milano: Casa Ed. Milanese, 1918), La piccola esploratrice: eroina dei boy-scouts d'Italia: racconto morale passionale (Milano: Milanese, 1919), Giovanna d'Arco, la Vergine guerriera: Romanzo storico (Firenze: G. Nerbini, 1928), Piccolo balilla: Bozzetto in un atto (Firenze: G. Nerbini, 1928), Turandot, la principessa capricciosa: Romanzo passionale. Dai racconti persiani di mille e un giorno (Firenze: G. Nerbini, 1928), Lady Godiva o la passeggiata della donna nuda: Romanzo di leggenda passionale (Firenze: G. Nerbini, 1928), Il vetturale del Moncenisio: riproduzione popolare (Firenze: G. Nerbini, 1928), Il re di Roma: Romanzo dell'epopea napoleonica. Fasc. I (Firenze: Nerbini, 1928), Il Re di Roma: romanzo dell'epopea napoleonica (Firenze: Nerbini, 1928), Una bella avventura: Romanzo allegro parigino (Firenze: Nerbini, 1928), Marinella: bozzetto marinaresco in 1 atto (Milano: Cesati, 1929), Cercasi moglie bella giovane.... e ricca: scketch in 1 atto (Milano: Casa Editrice Milanese, 1929), La forza del destino: Romanzo passionale. Dal dramma omonimo spagnolo (Firenze: G. Nerbini, 1929), Francesca da Rimini: Racconto storico (Firenze: G. Nerbini, 1929), Le avventure di Cyrano de Bergerac: Romanzo passionale (Firenze: G. Nerbini, 1929), Oberdan il martire di Trieste: dramma patriottico in 3 atti (Casa Editrice Milanese: Milano, 1929), Un amore sul lago di Como: Romanzo passionale (Firenze: G. Nerbini, 1929), Napoleone, il dominatore del mondo: Romanzo storico (Firenze: G. Nerbini, 1929), Leeredità del mendicante: Romanzo passionale. Da una leggenda araba (Firenze: G. Nerbini, 1930), La figlia del Sole: Romanzo fantastico (Firenze: G. Nerbini, 1930). 
Pubblicando questo volume abbiamo creduto di fare omaggio, al valore di un popolo, che sa battersi per la libertà della sua terra ${ }^{6}$.

Роман садржи шеснаест поглавља и главна јунакиња романа Софија Ипановић, ћерка старог Ипановића, појављује се у првом поглављу под насловом „Мржња расе”: прича започиње описом олује око шуме која се назива „Гвоздена врата” и која се пружа дуж планина Србије, те описом једног старог замка на врху планине, испод које тече Морава; Софија Ипановић жели да се бори против Мусфара, потомка расе коју проклиње, по систему lex talionis, јер он је учинио да њена мајка умре кад је хтео да је заведе. Сада када се Мусфаров син налази у турској војсци Софијин отац не зна како да се бори и ко би могао да им помогне и ту Софија предлаже да им у помоћ стигне њен вереник Димитрије, који би се на тај начин прославио у борби. На почетку другог поглавља („Фатална заклетва") стари Ипановић изриче заклетву пред смрт:

«E muoio con rammarico profondo di non saperlo debellato... scacciato... orà che un fremito di guerra è nell'aria... ora che tutti gli Stati balcanici si leveranno come un sol uomo e con un grido solo: - $\mathrm{Va}$ fuori o straniero!

Tacque. Ma per un attimo solo. La sua indomita fierezza non poteva frenarsi nemmeno all'appressarsi della morte.

- Quando la Serbia si leverà in armi - continuò con voce che viepiù s'affievoliva - lancia il tuo grido d'anatema contro l'oppressore. Incita i combattimenti a distruggere le stirpi maledette. Incita le donne dellantica Serbia che accorrevano sui campi di battaglia per incoraggiare i figli, i mariti, i fratelli... Sii eroina anche tu! Sii valorosa a preparare gli eroi! Sii degna del nome che tu porti! ${ }^{7}$

Софија се заклиње на коленима да ће се борити за домовину и за слободу, „као поносна вучица Србије” и отац још једном тражи од ћерке да се закуне:

6 BELLO 1913: [5]: „Славна епопеја Срба је маестрално описана у овом роману, пуном авантура и трагичних епизода, где се мешају једна тужна љубавна прича и узвишено јунаштво. / Објављујући ову књигу мислили смо да одамо почаст храбрости једног народа који зна да се бори за слободу своје земље." (прев. П. Л.)

7 BELLO 1913: 15: „«И умирем са дубоким жаљењем да нисам успео да га поразим... истерам... сада када је ратно узбуђење у ваздуху... сада када ће се подићи све балканске земље као једна и узвикнути: - Одлази туђине! / Заћута. Али само за тренутак. Његов несавладив понос није могао да се заустави ни пред смрћу. / - Када се Србија буде подигла на оружје - наставио је гласом који је био све слабији - баци анатему на тлачитеља. Подстакни на борбу да се уништи тај проклети род. Подстакни жене древне Србије које су јуриле на бојна поља да охрабре синове, мужеве, браћу... Буди и ти јунакиња! Буди храбра и припреми јунаке! Буди достојна имена које носиш!" (прев. П. Л.) 
Sì, Sofia, mia adorata Sofia, col tuo fidanzato, distruggi i nemici della tua terra... Ricordati ognora, quando muoverai all'assalto, che questo regno Serbo, patria di eroi leggendari, è stato l'ammirazione di tutto il mondo civile! ${ }^{8}$

Стари отац затим умире са жељом да умре Турчин Мусфар.

Треће поглавље („Идеални вереници”) отвара се описом „Гвоздене капије" Србије и гроба старог Ипановића, где се налази Софија са вереником Димитријем, који је обучен као војник јер га домовина зове у рат. Софија пита да ли и жене учествују у рату и сматра да није довољно да се само брину за мужеве и веренике, већ да се боре јер је света земља Србија за то створила жене (BELLO, 1913: 21). Млада Српкиња намерава да опонаша Српкиње из прошлости: заклиње се, на гробу својих предака, вечном љубављу Димитрију и одлучује да крене за Београд (четврто поглавље: „Полазак у рат”), па на овом месту описује се Београд у празничној атмосфери, као почетак нове ере, кад су сви одлучили да се боре за слободу:

Belgrado era tutta in festa. La capitale della Serbia, pavesata da arazzi e di bandiere, aveva l'aspetto di una città immersa nel gaudio. Infatti i serbi festeggiavano il principio di una êra nuova. Per ogni via era un tripudio ed un osanna per la libertà. Dopo secoli e secoli di prigionia tutto un popolo si risvegliava, ricorrendo alle armi.

Era quello un giorno memorabile e solenne.

Dalle piazze, dalle case, dai viottoli angusti, dai crocicchi, dappertutto, sbucavano, a frotte, i cittadini militarizzati.

Tutti indossavano una divisa. Pareva che il popolo serbo, come un sol uomo, fosse accorso alle armi per diventar soldato. ${ }^{9}$

Аутор наводи да се из оближње цркве чуло „Те Deum”, да је српски краљ поређао трупе, те да се појавила једна сјајна визија: група девојака коју

8 BELLO 1913: 16: „Да, Софија, моја љубљена Софија, са својим вереником, уништи непријатеље своје земље... Сећај се сваког часа, кад будеш прешла у напад, да се овом српском краљевству, домовини легендарних јунака, дивио сав цивилизован свет!” (прев. П. Л.)

9 BELLO 1913: 23-24: „У Београду се славило. Главни град Србије, украшен таписеријама и заставама, имао је изглед града који је сав у радости. / И доиста, Срби су славили почетак једне нове ере. На свим улицама је било весеље и чули су се покличи радости због слободе. После векова и векова заробљеништва, цео се народ будио, прибегавао оружју. / То је био незабораван и свечан дан. / Са тргова, из кућа, из уских уличица, са раскршћа, свугде, избијали су, у гомилама, милитаризовани грађани. / Сви су носили униформе. Чинило се као да се српски народ, као једно биће, дигао на оружје да би постао војник." (прев. П. Л.) 
је предводила плавокоса „Богиња битке”, тј. Софија Ипановић, којој је салутирао краљ, а њихову чету је назвао „Војском јунакиња”. На почетку следећег поглавља, које се назива „Вила војника”, српски војници су описани као снажни и весели, знају да изазивају смрт и једва чекају да се боре. Плавокоса јунакиња придружује се једној изабраној чети која се зове „Ловци слободе”. У шестом поглављу, „На стражи”, један део српске војске који се улогорио у близини непријатеља примећује да је Софија Ипановић нестала, па се рађају сумње да је можда издала српски народ, но њен вереник Димитрије је брани и објашњава да је она изузетна морална личност и да ће то историја показати, јер Софија би се пре убила него да изда свој народ. Софија је, међутим, отишла (седмо поглавље „Наша јунакиња”) међу редове непријатеља да набави храну за изгладнеле српске јунаке. У осмом поглављу, „Са сунцем у очима...”, Софија трчи по рововима и суочава се са Мусфаром, те Мусфар и остали Турци се повлаче се у тврђаву Мараск. Девето поглавље, „Јунаци домовине”, отвара се описом српских војника који ишчекују крај борбе на линији Скопља (аутор користи турски термин, Ускуб), док се Турци повлаче у тврђаву; Софија пак после двобоја са Мусфаром, лечи ране. Пита се, међутим, где је њен вереник и зашто се није борио уз њу и тада одлучује да крене у потрагу, уз пратњу неколико војника. У даљини види ватре на бојном пољу, гавране који лете, жене и мајке оних који су погинули. „Лепа као богиња рата", Софија се поставља на чело српских војника и по наредби напада тврђаву где су Турци (девето поглавље: „Опкољена тврђава”). Овом приликом аутор истиче како су српски војници навикли да слепо слушају наређења, јер, ипак до тврђаве није било лако. Софија налази Димитријеву зелену капу и схвата да су га Турци заробили. Међутим, да би се стигло до тврђаве у којој се налазе Турци, потребно је прећи преко „Моста смрти”, и Софија подстиче српске војнике: „Un buon Serbo non deve morire nel suo letto!”10, па, иако многи умиру на мосту, ипак успевају да опколе тврђаву. Софија тражи да разговара са турским командантом, за љубав домовине и свог вереника. То је тема дванаестог поглавља, које се назива „Споразум части”: тај командант је омржени Мусфар, који се диви храбрости младе Софије. Она објашњава Турчину да је дошла по свог вереника. Мусфар нуди да га ослободи ако она пристане да остане код њега. Софија пристаје и, у следећем поглављу („Кула затвореника”), успева да убеди свог вереника да напусти тврђаву, а затим у четрнаестом поглављу које носи наслов „Победити или умрети!”, Мусфар доводи Софију у своју собу и покушава да је загрли. Она прво тражи пропусницу, а затим вади нож и забада га у његов врат. Софија бежи из тврђаве, налази се са вереником и прво се распитује о српској војсци; Димитрије јој саопштава да

10 BELLO 1913: 65: „Храбар Србин не умире у свом кревету!” (прев. П. Л.) 
је војска спасена и, док тако беже, једно ђуле погађа Димитрија смртно у груди: једино што успева да изговори јесте: „Збогом љубави!”, како и гласи наслов поглавља. И док се Срби боре прса у прса са непријатељем, Софија баца анатему на Турке.

Последње поглавље је насловљено „Живело српско море!” - то је повик српске војске која се, после вишемесечног рата, налази пред Драчем. Софија, на чијем је лицу бол због смрти вереника, улази прва у град и изјављује:

-O patria mia! patria mia! - sclamò, sospirando. E gli occhi le si riempirono di lagrime, che, i più, scambiarono per lacrime di gioia. Fiori e baci le gittavano le donne, al suo passaggio; ma ella non udiva, non vedeva... Intorno a lei trasvolava unombra dorata... ${ }^{11}$

\section{4. Анализа драме L'eroe della Serbia. Dramma in 3 atti}

Драма из 1915, која се састоји од три чина, прича сличну, ако не и исту причу, али у мушкој верзији. У драми о српском јунаку такође се појављује на почетку опис олује око старог замка, али и списак лица, па тако видимо Ђорђа Ипановића, бившег српског пуковника, и његове синове: седамнаестогодишњег Рената и двадесетогодишњег Димитрија; ту је, затим, тридесетогодишњи Турчин Мусфар, те српски командант генерал и српски војници Карадов, Зогари и Поповић, заједно са другим турским и српским војницима и извиђачима:

GIORGIO IPANOVITCH - ex-colonnello Serbo.

RENATO - giovine diciasettenne.

\}suoi figli.

DIMITRI - ventenne.

MUSFAR - turco - sui trent'anni.

Comandante Serbo - generale.

Karadof -

Zogari - $\quad$ soldati serbi.

Popovich -

Soldati turchi e serbi - Sentinelle[.]

И овде стари Ипановић тражи од сина заклетву и узвикује како су се све 11 BELLO 1913: 92: „О, домовино моја! Домовино моја! - повика уздишући. И очи јој се напунише сузама које су се већини учиниле сузе радости. / Жене су јој бацале цвеће и пољупце кад је пролазила; али она их није чула, ни видела... Преко ње је прелетела златна сенка..." (прев. П. Л.) 
балканске земље дигле на борбу:

Soltanto muoio con rammarico per non aver visto scacciato il despota dalla nostra Patria! ......... il demone infernale......... ora che un fremito di guerra è nell'aria......... ora che tutti gli Stati Balcanici si son levati come un sol uomo, con un grido solo, formidabile: - E nostra questa terra! ${ }^{12}$

Ренато се куне да ће бити достојан древних јунака Србије, и на крају те прве сцене стари Ипановић умире. Следи, затим, веома кратка друга сцена, у којој се састају Ренато и Димитрије, и Ренато га обавештава да им је отац умро.

Радња другог чина, који се састоји од осам сцена, одиграва се на линији Ускуба, где се налазе шатори српских официра, а с друге стране Мораве се налази Мараск, тврђава у коју су се повукли Турци. Димитрије примећује да је Ренато нестао, а један други војник, Карадов, наглашава да није могуће да је дезертирао. Командант не жели да Димитрије крене у потрагу за својим братом, али он зна да је то његова дужност јер се Ренато регрутовао да би убио непријатеља. Као и Софија, и Ренато се преоблачи (у старца) да би ушао међу Турке и набавио храну за српске војнике, и у ствари он долази до једног савезничког града. Поставља се затим на чело једне чете која се зове „Ловци слободе”. Следи сцена двобоја између Рената и Мусфара, али Мусфар успева да побегне са моста и потом се чује српска химна, па овако стоји у сценском упутству: „Squilli di trombe. È l'Inno dei Serbi. L'Eroe, premendosi la mano sanguinante - che avrà fasciato con un fazzoletto - prende il vessillo che sventola. Ritto sul ponte, esclama: L'Aquila della Serbia vive ancora!"'13

Трећи чин се састоји од пет сцена и прва сцена се отвара у опкољеној тврђави, где Мусфару јављају да једна жена, наводно из Црвеног крста, жели да разговара са њим. На сцену улази Ренато који је преобучен у жену и има плаву перику. Тражи да Мусфар ослободи његовог брата и Мусфар ослобађа Димитрија, а затим Ренато открива ко је, вади нож, зарива га у Мусфара, бежи кроз прозор и последње његове речи су: „за Србију!”.

12 BELLO 1915: 11: „Само умирем са жаљењем што нисам видео деспота наше Домовине протераног!... паклени демон... сада када је ратно узбуђење у ваздуху... сада када су се подигле све балканске земље као једна, једним повиком, силно: - Ово је наша земља!" (прев. П. Л.)

13 BELLO 1915: 30: „Чују се трубе. То је химна Срба. Наш Јунак, притискајући руку која крвари - и коју је у међувремену повезао марамицом, узима заставу која се вијори. Усправан на мосту, узвикује: Орао Србије и даље живи!” (прев. П. Л.) 


\section{5. Компаративни приказ романа и драме}

Ако се ова два дела упореде, оно што привлачи пажњу јесте да L'eroina della Serbia и L'eroe della Serbia представљају, у ствари, женски (роман) и мушки (драма) примерак скоро истог догађаја. Штавише, ако се упоредо прате текстови, видеће се, пре свега у првом делу, скоро идентични фрагменти. Као пример ауторовог избора да предложи читаоцима мушки драмски пандан женске верзије романа навешћемо паралелно фрагмент првог поглавља романа и прве сцене првог чина драме:

Leroina della Serbia (1913)

$[\ldots]$

-Sofia - dimandò alla fine il vecchio come destandosi da un lungo torpore - la tempesta è cessata?

La fanciulla, sollevando i begli occhi celesti sul volto smunto paterno:

-No, padre mio - rispose, con soavità nella voce. - Imperversa più violenta ed accanita.

Il vecchio tese l'orecchio e raccolse tutto il suo respiro.

-Come la mia anima... rugge quella tempesta! - sclamò amaramente.

E fe' l'atto di alzarsi, dall'ampio seggiolone di cuoio antico, a borchie cesellate.

Ma non potè: le forze lo tradirono.

-Non posso - aggiunse, con profondo scoraggiamento.

La figlia congiunse le mani a preghiera.

-Ė imprudenza, la vostra, padre mio - fece, supplicando. - Non vi siete guarito ancora dell'ultimo attacco di paralisi e voi volete... Suvvia! desistete!

Il padre la guardò con occhio amorevole ed espressivo.

-E vero! - fece - la mia morte ti sarebbe fatale. Nemmeno un fratello Iddio ti ha concesso! Sei sola. E la tua esistenza diverrebbe più triste di adesso.

-Quali fantasmi, nella vostra mente, questa sera?

-Essi sono i fantasmi che si annidano qui, tra queste mura, da secoli e secoli!

«In queste ore di tempesta, mille ombre mi riddano dinanzi...

«Mi risvegliano delle sopite rimembranze.... Mi rievocano tutto il passato.

-Il passato è morto, padre mio!

-Ma i morti risorgono, ritornano, riempiono di singulti tutto questo castello, strisciano contro queste pareti; io li vedo, li sento: gridano: «Mi vendica! mi vendica!» Tu ben lo comprendi? Essi sono i nostri antenati; sono coloro che vissero per secoli e secoli nella schiavitù, sotto la dominazione e la tirannide turca; sono coloro che ci lasciarono il retaggio della vendetta. ${ }^{14}$

14 F. Bello: Leroina della Serbia. Romanzo patriotico, Milano 1913, 8-10: „[...] - Софија 
L'eroe della Serbia (1915)

[...]

Ipanovitch - Renato, la tempesta è cessata?

Renato - No, padre mio: imperversa più violenta.

Ipanov. - Come la mia anima rugge quella tempesta!

Renato - Scacciate le tristi idee. Pensate adaltro. Sollevate il vostro spirito.

Ipanov. - Non posso.

Renato - Andate, allora, a riposarvi.

Ipanov. - Il sonno sfugge dai miei occhi.

Renato - Ma così non potete rimanere. La vostra è un'imprudenza, padre mio. Voi non siete ancora guarito dell'ultimo attacco di paralisi. Suvvia! Deistete! .....

Ipanov. - (guardandolo espressivo) È vero. Non t'inganni. La mia morte ti sarebbe fatale.... Tua madre, quella santa donna! è morta! Una sorella, Iddio ti avea concesso, e gli Angeli se l'han portata in cielo......... Che più? Ti rimane solo un fratello, studente, lontano, a Belgrado.......... Oh come la tua esistenza diverrebbe più triste di adesso!

Renato - Quali fantasmi nella vostra mente questa sera!

Ipanov. - Essi sono i fantasmi che si annidano qui, tra queste mura, da secoli e secoli! In queste ore di tempesta mille ombre mi riddano dinanzi......... Mi risvegliano delle sopite rimembranze...... Mi rievocano tutto il passato.

Renato - Tutto ciò che è passato....... è morto, padre mio!

Ipanov. - Ma i morti risorgono, ritornano, riempiono di singulti tutto questo castello, strisciano contro queste pareti. Io li vedo, io li sento...... Gridano: "Mi vendica! mi vendica!......." Tu ben lo comprendi!?

- упита напокон старац као да се пробудио из дуге обамрлости - олуја је престала? / Девојка, подигавши лепе плаве очи према очевом узневереном лицу: / - Не, оче мој одговори нежним гласом. - Бесни још силније и жестоко. / Старац је слушао и дубоко удахнуо. / - Као моја душа... хучи та олуја! - узвикнуо је горко. / И начини покрет да устане из велике столице од старе коже са изрезбареним копчама. / Али није могао: издале су га снаге. / - Не могу - додаде, дубоко обесхрабрен. / Ћерка је склопила руке у молитву. / - Несмотрени сте, оче мој - рече преклињући. - Још се нисте опоравили од последњег напада парализе, а већ желите... Немојте! / Отац ју је гледао изражајним погледом љубави. / - Истина је! - рече - моја би ти смрт била фатална. Бог ти није дао ни брата! Сама си. И твој живот би постао још тужнији него што је сада. / - Који су то духови у вашој глави вечерас? / - То су духови који се гнезде међу овим зидовима, вековима и вековима! / «У овим тренуцима олује, хиљаде сенки играју врзино коло... / «Буде ме из успаваних успомена... Призивају ми сву прошлост. / - Прошлост је мртва, оче мој! / - Али мртви васкрсавају, враћају се, испуњавају плачом овај замак, пузе по овим зидовима; ја их видим, осећам их: узвикују: «Освети ме! Освети ме!» Да ли успеваш то да схватиш? То су наши преци; они који су вековима и вековима живели у ропству, под турском доминацијом и тиранијом; то су они који су нам у наслеђе оставили освету." 
Essi sono i nostri antenati; sono coloro che vissero per secoli e secoli nella schiavitù, sotto la dominazione e la tirannide turca: sono coloro che ci lasciarono il retaggio della vendetta. ${ }^{15}$

Иако је реч о делима тзв. лаке литературе, чињеница је да је Франко Бело, како са жанровске тако и са тематске тачке гледишта, био у суштини иновативан, у оквиру једне народњачко-популарне концепције малих издавача око Првог светског рата у Италији. Ако се узме у обзир шта је све Бело објавио, онда се са задовољством може закључити да су издавачке куће са којима је Бело сарађивао, а пре свега Бјети и Гала, ставиле на исту разину тематику везану за српску повест са делима славних европских аутора. Без сумње су борбе Срба за слободу могле бити инспиративне италијанским читаоцима у том датом повесном тренутку, али читалац се не може отети утиску да су српске теме биле прихваћене од стране италијанске читалачке публике у времену Првог светског рата заједно са бројним другим темама западноевропских култура.

\section{Цитирана литература}

Bello, Franco. 1913. Leroina della Serbia. Romanzo patriotico. Milano: Casa editrice Bietti.

Bello, Franco. 1915. Leroe della Serbia. Dramma in 3 atti. Vicenza: Libreria editrice Giovanni Galla.

Biagianti, Alessandra. 2007. Casa editrice italiana di Attilio Quattrini, 1909-1931. Firenze: Firenze libri.

Bonetti, Mario. 1960 (a cura di). Storia delleditoria italiana. Roma: Gazzetta del Libro, 1960.

15 F. Bello: L’eroe della Serbia. Dramma in 3 atti, Vicenza 1915, 7-8: „[...] Ипановић - Ренато, олуја је престала? / Ренато - Не, оче мој: бесни још силније. / Ипанов. - / - Као моја душа... хучи та олуја! / Ренато - Протерајте те тужне идеје. Мислите на нешто друго. Поправите расположење. / Ипанов. - Не могу. / Ренато - Идите онда да се одморите. / Ипанов. - Сан ми не долази на очи. / Ренато - Ма тако не можете остати. Несмотрени сте, оче мој. Још се нисте опоравили од последњег напада парализе. Немојте! ... / Ипанов. - (гледајући га изражајно) Истина је. Не вараш се. Моја би ти смрт била фатална... Твоја мајка, света жена! Мртва је! Бог ди је дао једну сестру, а анђели су је однели на небо...! Шта више? Остаје ти само један брат, студент, далеко, у Београду... Ох, како би твој живот постао још тужнији него што је сада! / Ренато - Који духови у вашој глави, вечерас! / Ипанов. - То су духови који се гнезде међу овим зидовима, вековима и вековима! У овим тренуцима олује, хиљаде сенки играју врзино коло... Буде ме из успаваних успомена... Призивају ми сву прошлост. / Ренато - Све што је прошло - мртво је, оче мој! / Ипанов. - Али мртви васкрсавају, враћају се, испуњавају плачом овај замак, пузе по овим зидовима. Ја их видим, осећам их... Узвикују: «Освети ме! Освети ме!...» Да ли успеваш то да схватиш? / То су наши преци; они који су вековима и вековима живели у ропству, под турском доминацијом и тиранијом; то су они који су нам у наслеђе оставили освету." 
Ciaccia, Patrizia. 2013 (a cura di). Editori a Milano (1900-1945). Repertorio. Milano: FrancoAngeli.

Ragone, Giovanni. 1997. Tascabili e nuovi lettori. In G. Turi (a cura di), Storia dell'editoria nell'Italia contemporanea. Firenze - Milano: Giunti Editore, 449-477.

Spadolini, Giovanni. 1995. La mia Firenze. Frammenti dell'età favolosa. Firenze: Le Monnier.

Tortotelli, Gianfranco. 2002. Tra le pagine. Autori, editori, tipografi nell'Ottocento e nel Novecento. Bologna: Pendragon.

Turi, Gabriele. 1999. L'intellettuale tra politica e mercato editoriale: il caso italiano. In A. Cadioli, E. Decleva, V. Spinazzola (a cura di), La mediazione editoriale. Milano: Il Saggiatore, 63-80.

Persida Lazarević Di Giacomo

\section{THE FIRST WORLD WAR IN ITALIAN LITERATURE: FRANCO BELLO AND HIS SERBIAN HEROES}

This paper deals with Serbian themes related to the Balkan wars and the First World War that are present in the works of Italian author Franco Bello, specifically in the novel L'eroina della Serbia. Romanzo patriotico ([Heroine from Serbia. Patriotic novel] Milano: Casa Editrice Bietti, 1913) and the drama Leroe della Serbia. Dramma in 3 atti ([Hero from Serbia. Drama in Three Acts] Vicenza: Libreria Editrice Giovanni Gallo, 1915). These works of popular literature appeared on the market in Italy at the time when 'light-literature' was just beginning to form a readership of its own. It is also of interest to note that the two works under consideration appear to be a female and male version of the same theme: the struggle for freedom of a Serbian heroine / Serbian hero against the Turks. 